\title{
PENERAPAN METODE WATERFALL PADA APLIKASI TOKO ONLINE BIMA KIRANA CIBITUNG
}

Ali Mulyanto ${ }^{1}$, Sarah Aulia Fathi Salam ${ }^{2}$,

${ }^{1}$ Program Studi Teknik Informatika, Fakultas Sains dan Teknologi Universitas Panca Sakti Bekasi

Jalan Kapten Sumantri Nomor 16 Cikarang Utara Kabupaten Bekasi, e-mail: alimulyanto.psub@gmail.com

${ }^{2}$ Program Studi Teknik Informatika, Fakultas Sains dan Teknologi Universitas Panca Sakti Bekasi

Jalan Kapten Sumantri Nomor 16 Cikarang Utara Kabupaten Bekasi, e-mail: sarah.afz99@ gmail.com

\section{ARTICLE INFO}

Article history:

Received : 9 - September - 2021

Received in revised form : 7 - Oktober - 2021

Accepted : 11 - Oktober - 2021

Available online : 16 - Oktober - 2021

\begin{abstract}
Bima Kirana Cibitung store is a store that faces problems in the marketing field, so that in marketing its products the store is less broad in scope, this makes the income earned by the store less fulfilled. The Bima online shop application is the answer to these problems. The system was developed using the waterfall method, while the application was made using the CodeIgniter framework and database using MySql. Based on blackbox testing, it was concluded that this application was running well. The purpose of this study is to create an online store application where customers can order goods online easily and quickly, so that the profits obtained by the store can be achieved.
\end{abstract}

Keywords: Online Shop, Waterfall, codeIgniter

\begin{abstract}
Abstrak
Toko Bima Kirana Cibitung adalah toko yang menghadapi masalah di bidang pemasarannya, sehingga dalam memasarkan produknya toko tersebut kurang luas cakupannya, ini membuat pendapatan yang di peroleh toko tersebut kurang terpenuhi. Aplikasi Toko online Bima menjadi jawaban dari permasalahan tersebut. Sistem dikembangkan dengan metode waterfall, sedangkan aplikasinya dibuat dengan pemrgoraman framework codeIgniter dan data base menggunakan MySql Berdasarkan pengujian blackbox yang dilakukan diperoleh kesimpulan bahwa aplikasi ini berjalan dengan baik. Tujuan dari penelitian ini adalah membuat aplikasi toko online dimana pelanggan dapat memesan barang secara online dengan mudah dan cepat, sehingga keuntungan yang diperoleh toko tersebut dapat tercapai
\end{abstract}

Kata Kunci: toko online, waterfall codeIgniter.

\section{PENDAHULUAN}

Toko Bima Kirana Cibitung merupakan toko yang berada di bergerak dalam bidang penjualan kebutuhan pokok. Toko Bima Kirana Cibitung berada di Kabupaten Bekasi, Jawa Barat. Toko ini masih membutuhkan ekspansi dalam bisnis penjualan produk yang disediakan oleh Toko Bima Kirana Cibitung. Saat ini sistem penjualan di toko ini masih manual yaitu masih menggunakan tulisan tangan untuk merekap datanya. Mengharuskan pelanggan datang ke toko atau membeli barang melalui Facebook untuk memesan dan mengetahui informasi produk. Kendala yang dirasakan oleh pelanggan adalah jarak yang jauh dari toko dan bagi pelanggan yang berada di luar Perumahan Kirana Cibitung serta memiliki kesibukan sehari-hari tidak memungkinkan untuk datang ke toko, sehingga pelanggan tidak sempat datang untuk berbelanja. Berdasarkan uraian tersebut, maka akan dilakukan penelitian dengan judul Perancangan Aplikasi Toko Online Bima Kirana Cibitung Menggunakan Metode Waterfall. 
Selama ini pemesanan barang di Toko Bima cukup sederhana, pelanggan harus login terlebih dahulu di Facebook untuk dapat melihat produk yang di promosikan setiap hari di grup jual beli khusus perumahan Kirana Cibitung. Pesanan barang dikirim jika sudah disetujui melalui inbox facebook atau komentar di facebook, kemudian permintaan barang pelanggan akan dicek jika persediaan habis, toko akan memberitahukan kepada pelanggan atau konfirmasi melalui komentar atau inbox facebook. Sedangkan pada saat barang masih tersedia, toko online akan merespon permintaan pelanggan yang terdiri dari harga barang dan daftar harga barang yang dipromosikan, jika pelanggan setuju toko akan mengirimkannya melalui Delivery Order (DO) yang artinya barang langsung dikirim setelah dipesan oleh pembeli. Dalam situasi pandemi COVID-19, banyak pelanggan yang menjalani isolasi mandiri atau larangan keluar rumah yang harus dipatuhi untuk mencegah penyebaran virus yang telah menyebar ke seluruh dunia. Pandemi COVID-19 membuat warga kesulitan memenuhi kebutuhan rumah tangga sehari-hari, yakni kebutuhan pokok. Untuk itulah aplikasi toko online dibuat untuk memudahkan toko dan pembeli dalam melakukan transaksi jual beli sembako melalui smartphone masing-masing.

\section{TINJAUAN PUSTAKA}

\subsection{Penelitian Terkait}

Pada penelitian yang berjudul "Penerapan Model Waterfall Dalam Pembuatan Aplikasi Toko Kado" menggunakan metode Entity Relationship Diagram (ERD) dan Logical Record Structure (LRS) untuk merancang database. Sedangkan Bahasa pemrograman menggunakan PHP dan database menggunakan MySql. Hasil penelitian menunjukkan bahwa pengunjung dan pelanggan mendapatkan kemudahan dalam mendapatkan informasi yang terkini melalui internet mengenai produk tanpa harus datang ke toko, memudahkan pelanggan melakukan pemesanan maupun pembelian, dan pada akhirnya website ini dapat meningkatkan efektifitas dan efisiensi dalam pengolahan data transaksi penjualan. [1]

Penelitian yang berjudul "Rancang Bangun Website Toko Online Menggunakan Metode Waterfall" bertujuan untuk mempermudah pelanggan dalam berbelanja, bertransaksi, berkonsultasi dengan pihak toko, mempermudah pelanggan untuk melihat produk secara detail, kapan saja, dimana saja serta mempermudah pelanggan melakukan pemesanan tanpa harus datang ke lokasi toko. Dan mempermudah pihak toko untuk membuat laporan data produk, melakukan promosi produk toko dan laporan penjualan. [2]

Penelitian yang berjudul "Rancang Bangun Aplikasi Penjualan Online Berbasis Web Pada Toko Spiccato Bandung" bertujuan untuk membantu masyarakat dalam melakukan transaksi pembelian dan penjualan dimana saja dan kapan saja dengan cara memanfaatkan internet sebagai media aksesnya dan membantu pihak toko dalam melakukan penjualan. Metode yang digunakan dalam pembuatan sistem ini dengan Unified Software Development Process yang terdiri dari tahapan Analisis, Perancangan, Implementasi, Deployment dan Pengujian. Pemodelan data dengan menggunakan Unified Modelling Language. Pengujian aplikasi menggunakan metode Black Box. Hasil dari penelitian ini berupa aplikasi penjualan online berbasis web pada Toko Spiccato Bandung dengan fasilitas stok produk, diskon pelanggan, pencarian produk, pemesanan dan pembelian produk, serta kolom testomoni.[3]

Penelitian yang berjudul "Penggunaan Bahasa Pemrograman PHP Dan MySQL Sebagai Penunjang Sistem Informasi Persediaan Dan Penjualan Secara Online" bertujuan untuk merancang suatu sistem baru dengan bahasa pemograman PHP dan database MySQL sehingga pengolahan data penjualan di Toko idola bangunan dapat dilakukan lebih baik dari sebelumnya. Mempermudah akses terhadap data yang dicari karena telah menggunakan database yang menampung keseluruhan data yang dirancang dengan program PHP. Dapat menghasilkan suatu informasi yang tepat,jelas,dan akurat bagi pihak toko, guna pengambilan keputusan dan dapat meningkatkan pelayanan kepada semua pihak yang terlibat. [4]

\subsection{Model Waterfall}

Model waterfall merupakan model pengembangan sistem informasi yang sistematik dan sekuensial.[5] Model waterwall juga merupakan model proses perangkat lunak yang melibatkan tahapan pengembangan terpisah: spesifikasi, desain, implementasi, pengujian, dan pemeliharaan. Pada prinsipnya, satu tahap harus diselesaikan sebelum maju ke tahap berikutnya. Tahapan model waterfall yaitu sebagai berikut [6].

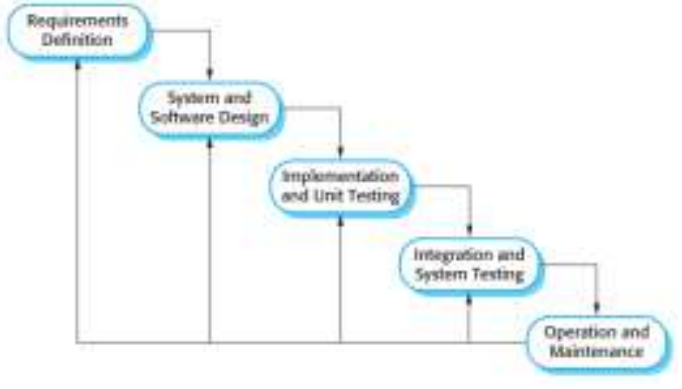

Gambar 1. Tahapan Model Waterfall 
Dari gambar 1 di atas dapat dijelaskan sebagai berikut.

1. Requirements definition

Layanan sistem, kendala, dan tujuan ditetapkan oleh hasil konsultasi dengan pengguna yang kemudian didefinisikan secara rinci dan berfungsi sebagai spesifikasi sistem.

2. System and software design

Tahapan perancangan sistem mengalokasikan kebutuhan-kebutuhan sistem baik perangkat keras maupun perangkat lunak dengan membentuk arsitektur sistem secara keseluruhan. Perancangan perangkat lunak melibatkan identifikasi dan penggambaran abstraksi sistem dasar perangkat lunak dan hubungannya.

3. Implementation and unit testing

Pada tahap ini, perancangan perangkat lunak direalisasikan sebagai serangkaian program atau unit program. Pengujian melibatkan verifikasi bahwa setiap unit memenuhi spesifikasinya.

4. Integration and system testing

Unit-unit individu program atau program digabung dan diuji sebagai sebuah sistem lengkap untuk memastikan apakah sesuai dengan kebutuhan perangkat lunak atau tidak. Setelah pengujian, perangkat lunak dapat dikirimkan ke customer

5. Operation and maintenance

Biasanya, tahapan ini merupakan tahapan yang paling panjang. Sistem dipasang dan digunakan secara nyata. Maintenance melibatkan pembetulan kesalahan yang tidak ditemukan pada tahapan-tahapan sebelumnya, meningkatkan implementasi dari unit sistem, dan meningkatkan layanan sistem sebagai kebutuhan baru.

\subsection{Framework Code Igniter}

Framework CodeIgniter adalah aplikasi open source berupa framework dengan model MVC (model, view, controller) untuk membangun website dinamis dengan menggunakan PHP. [7]

Kelebihan Framework CodeIgniter antara lain:

1. Mempercepat dan mempermudah membangun sebuah website

2. Mudah dalam perbaikan dan perawatan sistem

3. Tidak perlu dari fungsi-fungsi dari awal karena sudah disedian oleh framework.

4. Lebih Bebas dalam Pengembangan jika dibandungkan dengan CMS (Content Managemnent System)

\subsection{Unifield Modeling Languange (UML)}

UML merupakan bahasa pemodelan terpadu untuk menyediakan istilah kosakata umum berbasis objek dan teknik diagram untuk memodelkan proyek pengembangan sistem dari tahap analisis hingga tahap desain. UML terdiri dari 14 diagram yaitu (Class Diagram, Object Diagram, Package Diagram, Deployment Diagram, Component Diagram, Composite Structure Diagram, Activity Diagram, Sequence Diagram, Communicaton Diagram, Interaction Overviw Diagram, Timing Diagram, Behavioral State Machine, Protocol State Machine Dan Use Case Diagram). [8]

\section{METODOLOGI PENELITIAN}

3.1. Kerangka Pemiiran

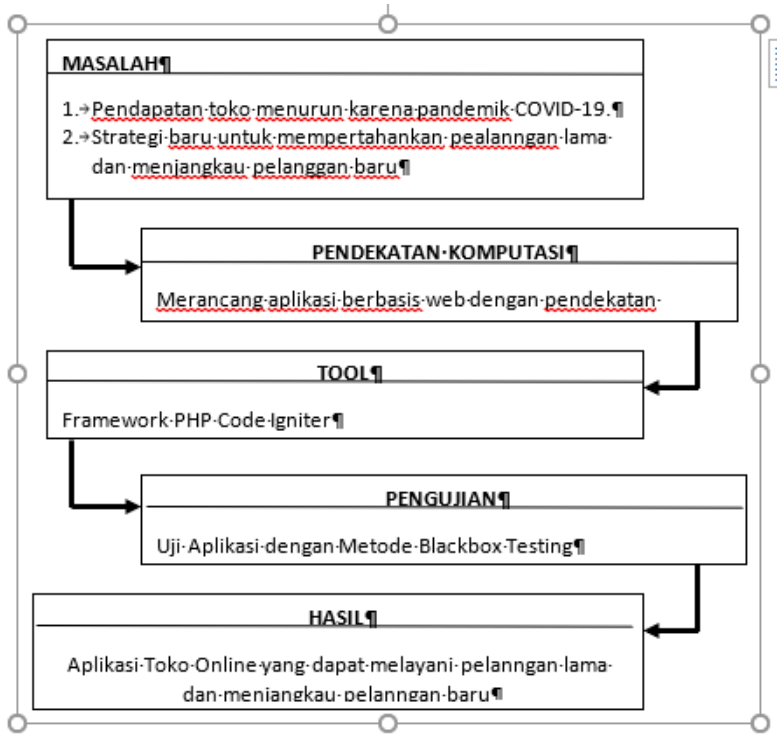

Gambar 2 Kerangka Pemikiran 


\subsection{Metode pengumpulan Data}

\subsubsection{Sumber Data}

Sumber data yang digunakan dalam penulisan laporan ini adalah data skunder. Data sekunder adalah data penelitian yang berupa tulisan, file atau informasi yang terlihat. Data yang di dapat dari toko adalah data barang, daftar harga, jenis produk, gambar produk dan lain-lain.

\subsubsection{Teknik Pengumpulan Data}

Teknik pengumpulan data yang digunakan dalam penelitian ini adalah metode wawancara dan studi pustaka. Metode wawancara digunakan untuk mengumpulkan data dari pemilik toko Bima, sedangkan metode studi pustaka dilakukan dengan memahami jurnal-jurnal dan buku buku yang terkait dengan penelitian yang dlakukan.

\subsection{Alat Penelitian}

Adapun alat yang digunakan untuk mendesain dan merancang sistem adalah Unified Modeling Language (UML). Pada penelitian ini, diagram UML yang digunakan antara lain: use case digaram dan class diagram. Use case diagram digunakan untuk mendokumentasikan persyaratan makro sistem berisi daftar kemampuan yang harus disediakan sistem sedangkan class diagram digunakan untuk menunjukkan kelas-kelas dalam suatu sistem dan hubungan antara kelas-kelas tersebut.[9] Program Aplikasi dikembangkan menggunakan bahasa pemrograman PHP framework CodeIgniter dan untuk database management system menggunakan MySql. [10]

\subsection{Metode Penelitian}

Metode penelitian yang diterapkan pada penelitian ini adalah dengan pengembangan metode waterfall. Metode Waterfall memiliki tahapan-tahapan sebagai berikut:

1) Requirements analysis and definition

Untuk mengetahui kebutuhan dari sistem yang akan dikembangkan, penulis melakukan metode wawancara terhadap pemilik toko dan untuk menambah utilitas sistem, penulis juga melakukan studi pustaka.

2) System and software design

Untuk menggambaran proses bisnis, penulis menggunakan alat bantu perangkat lunak UML. Proses bisnis pada sistem yang berjalan secara umum digambarkan dalam use case diagram. Sedangkan pada tahap perancangan sistem, penulis menggunakan acitivy diagram dan class diagram untuk menggambarkan sistem secara lebih detail.

3) Implementation and unit testing

Hasil perancangan sistem yang sudah disepakati oleh pemilik toko kemudian diterjemahkan ke dalam bahasa pemrograman. Penulis memilih pemrograman PHP dengan framework code igniter. Bahasa program ini dipilih dikarenakan open source dan bahasa yang aman untuk mengembangkan situs web. Bahasa PHP terdiri dari beberapa lapisan keamanan untuk mencegah utas dan serangan berbahaya.

4) Integration and system testing

Setelah proses coding selesai, kemudian dilakukan pengujian sistem. Pengujian sistem dilakukan untuk memastikan aplikasi terbebas dari kesalahan dan untuk menguji keamanannya. Blackbox tetsing dipilh untuk menguji kenyaman dan kesalahan program.

5) Operation and maintenance

Tahap terakhir yaitu membuat domain dan uploading file-file program ke webhosting.

\section{HASIL DAN PEMBAHASAN}

\subsection{Analisa Kebutuhan}

a. Identifikasi masalah

Dari hasil wawancara, dapat didentifikasi masalah sebagai berikut

1). Pendapatan toko menurun karena pamdemik COVID-19

2) Dibutuhkan startegi baru untuk mempertahankan pelanggan yang sudah ada dan menambah pelanngan baru

b. Kebutuhan Data

Data yang dibutuhkan dalam desain sistem toko online antara lain: profile toko, nama dan jenis barang yang dijual, promosi dan diskon yang diberikan, sistem pembayaran dan retur barang

c. Analisa sistem

1) Toko memajang barang di etalase toko, memasang harga barang dan diskon yang diberikan

2) Pelanggan memilih barang kemudian melakukan pembayaran di kasir

3) Kasir menyerahkan barang ke pelanggan.

\subsection{Desain Sistem}

a. Use case diagram 


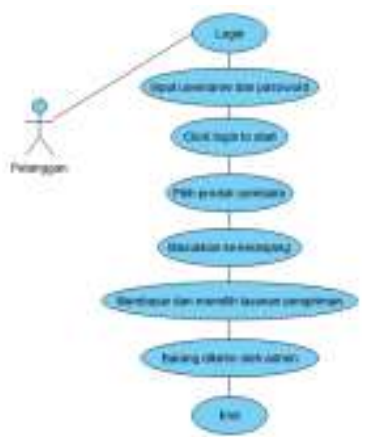

Gambar 3. Usecase Diagram sistem yang diusulkan

b. Class Diagram

\subsection{Implementasi Sistem}

a. Halaman Utama

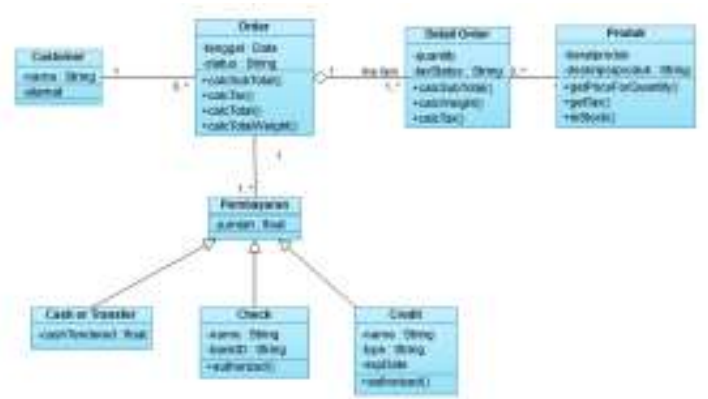

Gambar 4. Class Diagram

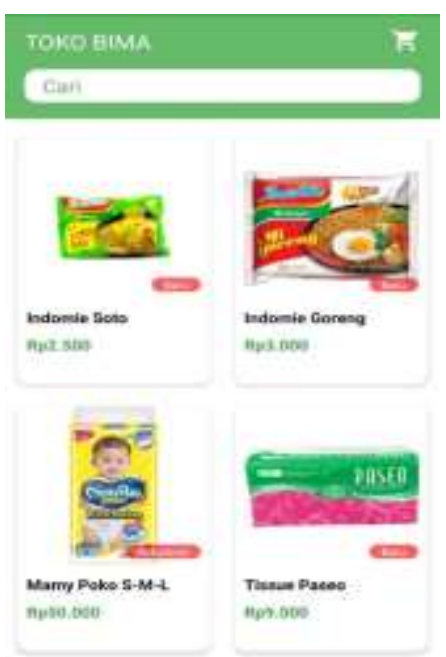

Gambar 5. Tampilan Menu Utama

b. Halaman Login

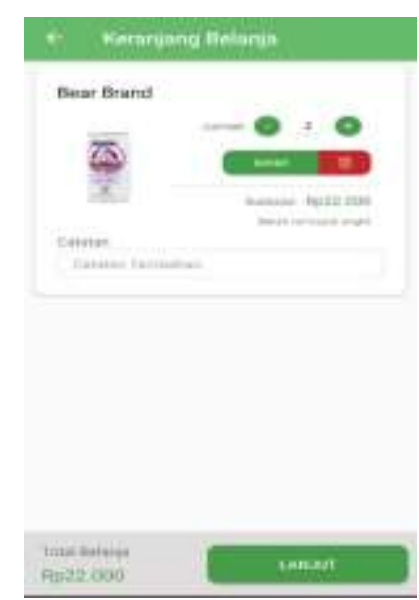

Gambar 6. Tampilan Keranja Belanja 
c. Halaman Login

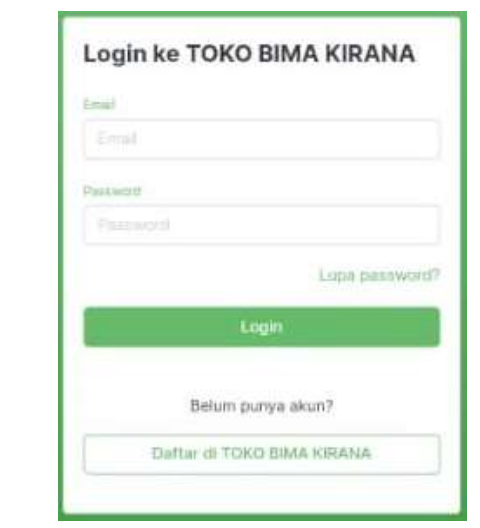

Gambar 7. Tampilan Halaman Login

d. Halaman Konfirmasi alamat dan metode pembayaran

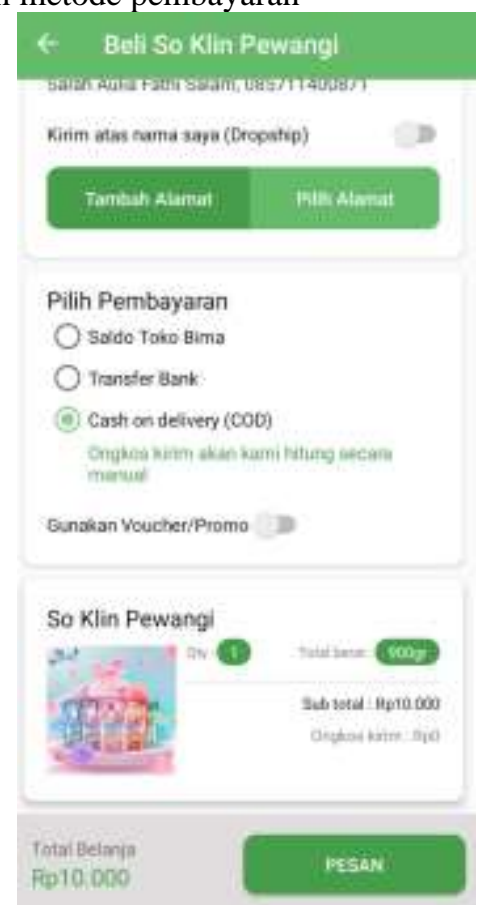

Gambar 8. Tampilan Halaman Konfirmasi metode Pembayaran

e. Halaman Konfirmasi Sukses

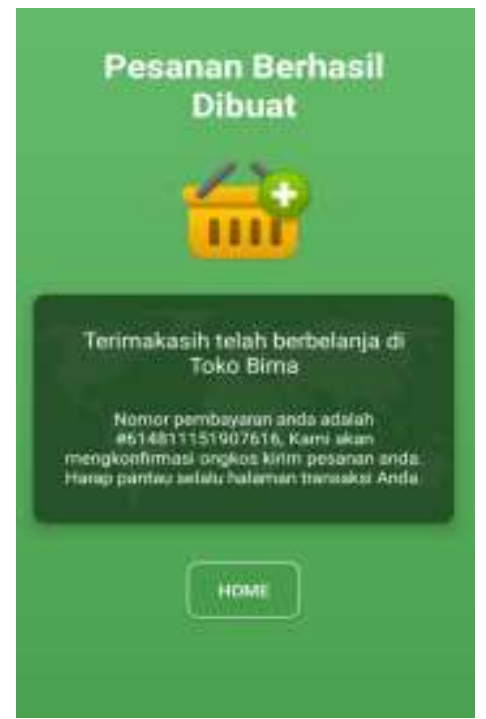

Gambar 9. Tampilan Halaman Konfirmasi Sukses 


\subsection{Integrasi dan Pengujian Sistem}

Dalam penelitian ini rancangan pengujian sistem dilakukan dengan melakukan pengujian black-box terhadap semua fungsi dalam aplikasi. Pengujian black-box merupakan salah satu pengujian aplikasi atau perangkat lunak yang berfokus pada persyaratan fungsional perangkat lunak. Karena itu uji coba black-box memungkinkan pengembang software untuk membuat himpunan kondisi input yang akan melatih seluruh syaratsyarat fungsional suatu program. Tabel 1 menunjukkan hasil pengujian sistem.

Tabel 1 Hasil pengujian sistem

\begin{tabular}{|c|c|c|c|c|c|}
\hline no & pengujian & test case & $\begin{array}{l}\text { hasil yang } \\
\text { diharapkan }\end{array}$ & hasil pengujian & kesimpulan \\
\hline 1. & $\begin{array}{l}\text { saat mengisi } \\
\text { username dan } \\
\text { password }\end{array}$ & $\begin{array}{l}\text { klik } \\
\text { username } \\
\text { dan } \\
\text { password }\end{array}$ & login berhasil & sesuai harapan & $\begin{array}{l}\text { valid, login } \\
\text { berhasil }\end{array}$ \\
\hline 2. & $\begin{array}{l}\text { melihat } \\
\text { gambar } \\
\text { produk, harga } \\
\text { dan kategori } \\
\text { produk }\end{array}$ & $\begin{array}{l}\text { klik produk } \\
\text { dan kategori } \\
\text { produk }\end{array}$ & $\begin{array}{l}\text { muncul } \\
\text { produk, } \\
\text { harga, dan } \\
\text { kategori }\end{array}$ & $\begin{array}{l}\text { sesuai harapan. } \\
\text { produk muncul } \\
\text { saat di klik }\end{array}$ & valid \\
\hline 3. & $\begin{array}{l}\text { menyimpan } \\
\text { produk di } \\
\text { keranjang } \\
\text { belanja }\end{array}$ & $\begin{array}{l}\text { klik } \\
\text { keranjang } \\
\text { dan pilihan } \\
\text { satuan } \\
\text { produk }\end{array}$ & $\begin{array}{l}\text { produk } \\
\text { muncul di } \\
\text { keranjang, } \\
\text { dan bila } \\
\text { memilih } \\
\text { beberapa } \\
\text { produk akan } \\
\text { dihitung } \\
\text { menurut } \\
\text { harga }\end{array}$ & $\begin{array}{l}\text { aplikasi } \\
\text { mengkalkulasikan } \\
\text { harga dan } \\
\text { barang }\end{array}$ & valid \\
\hline 4 & $\begin{array}{l}\text { ongkir sesuai } \\
\text { jarak dan } \\
\text { terintegrasi } \\
\text { raja ongkir }\end{array}$ & $\begin{array}{l}\text { pilih jasa } \\
\text { kirim dan } \\
\text { alamat yang } \\
\text { dituju }\end{array}$ & $\begin{array}{l}\text { pemilihan } \\
\text { jasa kirim dan } \\
\text { ongkir } \\
\text { berhasil }\end{array}$ & $\begin{array}{l}\text { pemillihan jasa } \\
\text { kirim dan ongkos } \\
\text { kirim sukses. }\end{array}$ & valid \\
\hline
\end{tabular}

Dari hasil pengujian yang dilakukan pada sepuluh dapat disimpulkan bahwa aplikasi membantu pengguna dalam mendapatkan barang dan harga yang terbaru.

\subsection{Operasional dan Perawatan sistem}

Operasionalisasi dirancang agar dapat dilakukan di toko Bima Kirana Cibitung. Sedangkan pemeliharaan sistem dirancang dengan dilakukannya pemeriksaan periodik terhadap data pada aplikasi.

\section{KESIMPULAN DAN SARAN}

Berdasarkan kesimpulan dari penelitian yang dilakukan, adalah sebagai berikut:

1. Desain aplikasi Toko Bima memberikan fitur-fitur yang memberikan kemudahan untuk pemilik toko dan pelanggan.

2. Rancangan aplikasi menggunakan metode Waterfall dimana setiap tahapan dilakukan persetujuan antara penulis dan pemilik toko sehingga menghasilkan program yang terbaik.

3. Diharapkan pemilik toko dapat meningkatkan pangsa pasar dengan biaya operasional yang murah karena transaksi bisnis online dapat dilakukan dimana saja.

\section{DAFTAR PUSTAKA}

[1] Apriyanto, Fatimah Amalia Salwa, "Penerapan Model Waterfall Dalam Pembuatan Aplikasi Toko Kado," IJCIT (Indonesian Journal on Computer and Information Technology), vol. 3, no. 2, p. 234 242, 2018.

[2] Muhammad Susilo, Rezki Kurniati, "Rancang Bangun Website Toko Online Menggunakan Metode Waterfall," InfoTekJar (Jurnal Nasional Informatika dan Teknologi Jaringan), vol. 2, no. 2, pp. 98$105,2018$. 
[3] Nita Novianti Firmansyah and Asri Mulyani, "Rancang Bangun Aplikasi Penjualan Online Berbasis Web Pada Toko Spiccato Bandung," Jurnal Algoritma, vol. 14, no. 2, pp. 572 - 581, 2017.

[4] Tiara Nabila Putri, Rifnaldi, Surmayanti, "Penggunaan Bahasa Pemrograman PHP Dan MySQL Sebagai Penunjang Sistem Informasi Persediaan Dan Penjualan Secara Online," Jurnal Pendidikan Teknologi Informasi, vol. 2, no. 2, pp. 64-73, 2019.

[5] R. S. Pressman, Software engineering : a practitioner's approach 7th ed., New York: McGraw-Hill, 2010.

[6] I. Sommerville, Software engineering -9th ed., Boston: Addison-Wesley, 2011.

[7] Supono \& Vidiandry Putratama, Pemrograman web dngan menggunakan PHP dan Framework CodeIgniter, Sleman: Deepublish, 2018.

[8] Alan Dennis, Barbara Haley Wixom, David Tegarden, System Analysis And Design, Hoboken,: John Wiley \& Sons, Inc, 2009.

[9] P. Kimmel, UML DEMYSTIFIED, New York: The McGraw-Hill Companies, 2005.

[10] S. Jaiswal, "Javatpoint.com," Javatpoint, 2016. [Online]. Available: https://www.javatpoint.com/codeigniter-tutorial. [Accessed 20 July 2021]. 